\title{
KUALITAS PELAYANAN \\ PROYEK OPERASI NASIONAL AGRARIA (PRONA) DI KECAMATAN MATTIRO SOMPE KABUPATEN PINRANG
}

\author{
Nurul Munia ${ }^{1}$, Muhlis Madani $^{2}, \mathbf{A b d i}^{3}$ \\ 1)Jurusan Ilmu Administrasi Negara FisipUnismuh Makassar \\ 2) Jurusan Ilmu Administrasi Negara FisipUnismuh Makassar \\ 3)Jurusan Ilmu Administrasi Negara FisipUnismuh Makassar
}

\begin{abstract}
ABSTRACK
The purpose of this research is not only aimed to know the service quality but also to know the supporting and inhibiting factors of the public service in Prona. This research used qualitative research type which is choosen by certain sample who had knowledge about Prona Service Quality. The research result showed that 1) if the required file was completed then the certificate could be quickly resolved 2) the service flow could be said "good" 3) the employee had not done the best in their work 4) PRONA activites will be completed within one budget a year 5) public enthusiasm in enrolling their land by Prona 6) the less of surveyor staff become the most inhibiting factor of Prona service.
\end{abstract}

Keywords: Quality, service, PRONA

\begin{abstract}
ABSTRAK
Tujuan dari penelitian ini tidak hanya untuk mengetahui kualitas pelayanan Prona tetapi juga untuk mengetahui faktor pendukung dan penghambat pelayanan publik. Jenis penelitian ini yang di gunakan adalah kualitatif dengan memilih orang tertentu yang anggap memiliki pengetahuan tentang Kualitas Pelayanan Prona. Hasil penelitian yang didapatkan yaitu 1) Apabila berkas yang di perlukan lengkap maka sertifikat cepat terselesaikan 2) alur Pelayanan sudah dapat dikatakan baik 3) Sikap Santun dan ramah petugas dalam memberikan pelayanan belum maksimal 4) PRONA akan di selesaikan dalam satu tahun Anggaran 5) antusias warga untuk mendaftarkan tanahnya melalui Prona 6) kurangnya tenaga pengukuran yang menjadi penghambat Pelayanan.
\end{abstract}

Kata Kunci : Kualitas, Pelayanan, PRONA 


\section{PENDAHULUAN}

\section{Berdasarkan Seminar Hukum}

Pertanahan pada tahun 1987

dikemukakan bahwa untuk memperoleh sertifikat diperlukan waktu lama, dan biayayang ralatif tinggi dan belum adanya sinkronisasi antara instansi pemerintah yang bersangkutan dengan pendaftaran tanah. Terdapat faktor-faktor lain yang bersifat nonteknis yang juga melatar belakangi lahirnya, yakni adanya sikap instansi Agraria yang bersifat pasif. Menunggu kehadiran anggota masyarakat (pemagang hak atas tanah) yang berkeinginan untuk mendaftarkan hak atas tanahnya.

Dengan cara kerja demikian, pekerjaan menjadi berjalan sangat lambat Selain itu, dijumpai sementara oknum aparat yang mempunyai mentalitas tidak terpuji, bukan membantu rakyat (pemegang hak atas tanah), tetapi justru membodohinya, karna tingkahnya itu timbul citra kurang baik terhadap instansi agraria.Kedua, siklus agraria pada waktu itu kurang terpadu, artinya tugas dan fungsi keagrariaan dengan segala seginya belum berjalan sebagai mana mestinya. Masing-masing fungsi berjalan sendiri-sendiri dan terkotak-kotak. Dengan kompleksnya masalah pendaftaran tanah tersebut, pemerintah menyelenggaran Proyek Operasi Nasional Agrari118a (PRONA) berupa penseritifikatan tanah secara massal dan penyelesaian sengketa-sengketa tanah yang bersifat strategisProgram pendaftaran tanah yang di khususkan untuk rumah tangga yang berpenghasilan rendah.Sebenarnya penyelenggaraan Prona ini menegaskan:"untuk menjamin kepastian hukum oleh pemerintah diadakan pendaftaran tanah di seluruh wilayah Republik Indonesia menurut ketentuanketentuan yang di atur dengan peraturan pemerintah".Tujuan diselenggarakannya Prona, antara lain sebagai berikut:Memberikan rangsangan kepada masyarakat khususnya pemegang hak atas tanah, untuk bersedia membuatkan sertifikat, 2) Menumbukan kesadaran hukum masyarakat dalam bidang pertanahan, 3) membantu pemerintah dalam hal menciptakan suatu suasana kehidupan masyarakat yang aman dan tenteram, 4) menumbuhkan partisipasi masyarakat, khususnya pemilik tanah dalam menciptakan 
stabilitas politik serta pembangunan di bidang ekonomi,menumbuhkan rasa kebersamaan dan tutur membantu pemerintah dalam menyelesaikan sengketa-sengketa pertanahan, 6) memberikan kepastian hukum kepada pemegang hak atas tanah, 7) membiasakan masyarakat pemilik tanah untuk mempunyai alat bukti autentik atas haknya tersebut. Peraturan perundang-udangan yang mengatur PRONA memang tidak memberikan penjelasan yang konkret mengenai siapa golongan ekonomi lemah tersebut, apa kriteria, ciri-ciri, dan syarat-syarat hingga seseorang termasuk golongan ekonomi lemah. Barangkali pembentukan undangudang tersebut beranggapan bahwa hal ini sudah cukup jelas dan tidak akan menimbulkan permasalahan di kemudian, sehingga tidak perlu ada penjelasan tersendiri. yang tidak atau kurang mampu, mereka di bebaskan untuk tidak di bebani dengan biayabiaya pendaftaran, kecuali untuk mereka yang termasuk golongan mampu dan bagi pemilik tanah, dengan adanya sertifikat itu memastikan haknya atas tanahnya, dan selanjutnya dapat di kelola dan di garap dengan sebaik-baiknya.
Kualitas pelayanan atau customer service ini dapat dibedakan ke dalam dua kriteria yaitu jenis kualitas pelayanan yang baik dan kualitas pelayanan yang buruk. Kualitas pelayanan ini bukanlah suatu hal yang permanen atau kaku, melainkan fleksibel dan dapat dirubah. Perubahan ini tentunya berupa peningkatan kualitas pelayanan agar semakin lebih baik lagi. Dilihat Dari sudut pandang pelaynan . Hardiansyah (2010:22).

kualitas pelayanan di instansi pemerintahan telah memiliki standarstandar tersendiri yang harus dipenuhi Salah satu tempat yang memerlukan perhatian terkait kualitas pelayanannya adalah instansi pemerintahan. Kerap kali kita mengeluh tentang pelayanan di instansi pemerintahan yang cenderung kurang atau tidak memenuhi kriteria yang diharapkan. Sebagai konsekuensi dari pelaksanaan Otonomi Daerah terlebih setelah ditetapkannya UndangUndang nomor 32 Tahun 2004 tentang Pemerintahan Daerah, dimana Pemerintahan Daerah diberi kewenangan yang demikian luas oleh pemerintah pusat untuk mengatur 
rumah tangga daerahnya sendiri, termasuk didalamnya adalah pemberian pelayanan kepada masyarakat di daerahnya. Namun berbagai isu yang muncul di kalangan masyarakat, ternyata hak pelayanan yang diterima oleh masyarakat terasa belum memenuhi harapan semua pihak baik dari kalangan masyarakat umum maupun dari kalangan pemerintah sendiri. Jadi tidak heran lagi sering mendengarkan tuntutan perubahan sering ditujukan kepada aparatur pemerintah, menyangkut pelayanan publik yang di berikan kepada masyarakat.

Kualitas merupakan suatu kondisi dinamis yang berhubungan dengan hasil kerja, manusia/tenaga kerja, proses dan tugas, serta lingkungan yang memenuhi atau melebihi harapan konsumen atau masyarakat (Nasution, 2005: 3).

Dilihat dari sudut manajemen operasional, kualitas pelayanan merupakan salah satu kebijaksanaan penting dalam meningkatkan daya saing produk yang harus memberi kepuasan kepada masyarakat melebihi atau paling tidak sesuai dengan tandarisasi kualitas pelayanan. Kualitas pelayanan memiliki hubungan yang erat dengan tingkat kepausan seseorang.

Faktor-faktor pendukung yang sangat penting yang apabila dari salah satu dari faktor tersebut tidak ada, maka pelayanan akan sangat terasa kurang maksimal. Dibawah ini adalah penjelasan menurut Ridwan dan Sodik Sudrajat (2009:22) mengenai faktor-faktor pendukung peningkatan pelayanan publik adalah, (a) Faktor Hukumakan mudahditegakkan, jika aturan atau undang-undangnya sebagai sumber hukum mendukung terciptanya dengan kebutuhan untuk terciptanya penyelenggaraan pelayanan publik. (b)Faktor Aparatur Pemerintah Aparatur pemerintah merupakan salah faktor terciptanya peningkatan pelayanan publik. Oleh karena aparat pemerintah merupakan unsur yang bekerja didalam pratek untuk memberikan pelayanan. (c) Faktor Sarana Penyelenggaraan pelayanan publik tidak akan berlangsung dengan lancar dan tertib (baik). Jika tanpa adanya suatu sarana atau fasilitas yang mendukungnya. Sarana itu mencakup tenaga manusia yang berpendidikan, organisasi yang baik, peralatan yang memadai dan keuangan yang cukup. Jika hal-hal 
yang demikian itu tidak terpenuhi, maka mustahil tujuan dari pelayanan publik akan tercapai dengan baik atau sesuai dengan harapan. Meskipun faktor-faktor hukum, aparat penegak hukum dan kesadaran hukum, masyarakat sudah dapat dipenuhi dengan baik namun jika fasilitas yang tersedia kurang memadai.Sebelumnya telah di jelaskan yakni sebuah pembahasan dan penjelasan dari faktor penghambat pelayanan publik.

Adapun faktor penghambat dalam hal ini dapat memperlambat proses pemberian pelayanan kepada masyarakat.Dan berikut menurut Zeithmal (dalam Kurniawan, 2005:24), yang mengatakan bahwa terdapat 4 jurang pemisah yang menjadi kendala di dalam pelayanan publik yakni sebagai berikut: 1 . Tidak tahu apa sebenarnya yang diharapkan oleh masyarakat. 2. Pemberian ukuran yang salah dalam pelayanan masyarakat 3.Keliru dalam penampilan diri dalam pelayanan itu sendiri.4. Ketika membuat perjanjian terlalu berlebihan atau pengobralan.

Menurut Tjiptono (2011:33), kualitas pelayanan adalah suatu keadaan dinamis yang berkaitan erat dengan produk, jasa, sumber daya manusia, serta proses dan lingkungan yang setidaknya dapat memenuhi atau malah dapat melebihi kualitas pelayanan yang diharapkan. Menurut Tjiptono, definisi kualitas pelayanan ini adalah upaya pemenuhan kebutuhan yang dibarengi dengan keinginan konsumen serta ketepatan cara penyampaiannya agar dapat memenuhi harapan dan kepuasan pelanggan tersebut. Dalam kualitas pelayanan yang baik, terdapat beberapa jenis kriteria pelayanan, antara lain adalah (1) Ketepatan waktu pelayanan, termasuk didalamnya waktu untuk menunggu selama transaksi maupun proses pembayaran.(2) Akurasi pelayanan, yaitu meminimalkan kesalahan dalam pelayanan maupun transaksi.(3)Sopan santun dan keramahan ketika memberikan pelayanan.(4) Kemudahan mendapatkan pelayanan, yaitu seperti tersedianya sumber daya manusia untuk membantu melayani konsumen, serta fasilitas pendukung seperti komputer untuk mencari ketersediaan suatu produk.(5) Kenyaman konsumen, yaitu seperti lokasi, tempat parkir, ruang tunggu yang nyaman, aspek kebersihan, 
ketersediaan informasi, dan lain sebagainya.

Pensertifikatan secara massal massal melalui Prona dilaksanakan untuk menciptakan kepastian hukum atas bidang-bidang tanah di indonesia,dapat dipastikan pula hakhak dan status yang berkenaan dengan pemilik tanah, sehingga dengan demikian segala kemungkinan keresahan, ketegangan, perselisihan dan pertikaian, dapat diletakan pada landasan-landasan hukum yang jelas.( Sutedi, 2014:68)

Menurut Soebekti dan R. Tjitrosoedibio (2011)Hukum Agraria (Agrarich Recht), adalah keseluruhan dari ketentuan-ketentuan hukum, baik Hukum Perdana maupun Tata Negara( Staatsrecht) yang mengatur hubungan-hubungan antara orang termasuk badan hukum bumi, air, dan ruangan angkasa dalam seluruh wilayah negara dan mengatur pula wewenang-wewenang yang bersumber hubungan-hubungan tersebut. Hak Milik belum terbentuk,maka yang berlaku adalah ketentuan-ketentuan Hukum Adat setempat dan peraturan-peraturan lainnya sepanjang tidak bertentangan dengan UUPA.(Santoso 2014:92)

Dengan berlakunya undang-undang Nomor 5 1960tentang peraturan Dasar Pokok-Pokok Agraria (UUPA) dan peraturan pelaksanaannya, maka pemerintah telah membuat suatu kebijakan untuk meningkatkan.Kualitas pelayanan tidak hanya diharapkan dan dinilai dari perusahaan-perusahaan yang menjual produk yang diinginkan.Beberapa pelayanan yang kerap harus diperhatikan untuk pelayanan masyarakat diantaranya adalah di bidang kualitas pelayanan kesehatan, kualitas pelayanan jasa, kualitas pelayanan prima, kualitas pelayanan hotel, kualitas pelayanan akademik, dan kualitas pelayanan bank. Beberapa instansi seperti rumah sakit, bank, hotel, dan universitas, memiliki standar kualitas pelayanan masing-masing. Namun umumnya masyarakat juga memiliki penilaian dan harapan kualitas pelayanan tersendiri dari masing-masing instansi tersebut.

Jenis-Jenis Pelayanan 


\section{Pelayanan}

pemerintahanAdalah jenis pelayanan masyarakat yang terkait dengan tugas-tugas umum pemerintahan seperti pelayanan KTP,SIM,pajak, dan keimigrasian. b. Pelayanan pembangunanSuatu jenis pelayanan masyarakat yang terkait dengan penyediaan sarana dan prasarana untuk memberikan fasilitasi kepada masyarakat dalam melakukan aktivitasnya sebagai warga Negara.Pelayanan ini meliputi penyediaan jalan-jalan. C. Pelayanan utilitasJenis pelayanan yang terkait dengan utilitas bagi masyarakat, seperti pelayanan listrik, air, telepon, dan transportasi massal. D. Pelayanan sandang, pangan, Dan papanMerupakan jenis pelayanan yang menyediakan bahan kebutuhan pokok masyarakat dan kebutuhan perumahan, seperti penyedian beras, gula, minyak, gas, tekstil, dan perumahan rumah. E. Pelayanan kemasyarakatanYaitu jenis pelayanan masyarakat yang dilihatdari sifat dan kepentingannya lebih ditekankan pada kegiatan-kegiatan sosial kemasyarakatan, seperti pelayanan kesehatan, pendidikan, ketenagakerjaan, penjara, rumah yatim piatu, dan lainnya.Sedangkan Kepmen PAN nomor 58 Tahun 2002 mengelompokkan tiga jenis pelayanan dari instansi pemerintah serta BUMN/BUMD.Pensertifikatan secara massal massal melalui Prona dilaksanakan untuk menciptakan kepastian hukum atas bidang-bidang tanah di indonesia,dapat dipastikan pula hak-hak dan status yang berkenaan dengan pemilik tanah, sehingga dengan demikian segala kemungkinan keresahan, ketegangan, perselisihan dan pertikaian, dapat diletakan pada landasan-landasan hukum yang jelas.( Sutedi, 2014:68)

Bagi pemilik tanah, dengan adanya sertifikat itu memastikan haknya atas tanahnya, dan selanjutnya dapat dikelola dan digarap dengan sebaik-baiknya dimanfaatkan dengan efektif dan seefisien mungkin untuk meningkatkan taraf hidupnya.(Sutedi, 2014:69).

\section{METODE PENELITIAN}

Waktu penelitian ini dilaksanakan selama 2 (dua) bulan. Dari bulan Februari- Maret 2018. Lokasi penelitian dilaksanakan di kantor BPN ( Nadan Pertanahan 
Nasional) di jalan Sukawati yang terkhusus di Kecamatan Mattiro Sompe Kelurahan Pallameang. Jenis penelitian yang di gunakan peneliti adalah jenis penelitian kualitatif dan tipe penelitian deskriptif yaitu untuk mengetahui atau menggambarkan kenyataan dari kejadian yang diteliti. Sumber data yakni data primer data sekunder. Informan penelitian yakni dari kantor BPN (Badan Pertanahan Nasional) dan Lurah, Lingkungan di Kelurahan Pallameang serta masyarakat yang menerima Prona. Dalam penelitian ini, pengumupulan data dilakukan melalui beberapa teknik yakni wawancara, observasi, dan dokumentasi.

Informan adalah orang yang benarbenar mengetahui atau pelaku yang terlibat lansung dengan permasalahan penelitian tentang kualitas pelayanan Prona. Memlih orang yang dianggap paling tau tentang apa yang kita harapka atau mungkin dia sebagai penguasa sehingga akan memudahkan peneliti dalam menjelajahi objek sosial yang di teliti.Teknik analisis data digunakan dengan cara interaktif dan berlangsung secara terus menerus sampai datanya jenuh. Ukuran kejenuhan data ditandai dengan tidak diperolehnya lagi informan baru.

\section{HASIL DAN PEMBAHASAN}

Berdasarkan dengan Tujuan penelitian ini yang tercantum pada sebelumnya, yaitu untuk mengetahui Bagaimana Kualitas Pelayanan Prona di Kecamatan Mattiro Sompe Kabupaten Pinrang dan mengetahui Bagaimana Faktor Pendukung dan Penghambat Kualitas Pelayanan Publik di Kecamatan Mattiro SompE.Luas wilayah kabupaten pinrang adalah 1.961,77 Km2 yang terdiri dari tiga dimensi kewilayahan meliputi dataran rendah, laut dan dataran tinggi. Secara administratif Kabupaten pinrang terdiri dari 12 kecamatan, 39 kelurahah dan 69 desa. Kecamatan yang berada dalam wilayah kabupaten pinrang yaitu kecamatan suppa, kecamatan mattiro sompe, kecamatan lanrisang, kecamatan mattiro bulu, kecamatan watang sawitto, kecamatan paleteang, kecamatan tiroang, kecamatan patampanua, kecamatan cempa, kecamatan duampanua, kecamatan batulappa dan kecamatan lembang. Dari 12 wilayah kecamatan, Kecamatan lembang merupakan wilayah terluas yaitu 733,03 Km2 dan 
kecamatan paleteang yang merupakan wilayah kecamatan terkecil dengan luas wilayah $37,29 \mathrm{Km} 2$.

Badan Pertanahan Nasional (BPN) adalah Lembaga Pemerintah Non Departemen yang berada di bawah dan bertanggung jawab kepada Presiden dan dipimpin oleh Kepala. (Sesuai dengan Perpres No. 10 Tahun 2006) Badan Pertanahan Nasional mempunyai tugas melaksanakan tugas pemerintahan di bidang pertanahan secara nasional, regional dan sektoral. Badan pertanahan nasional terbentuk sesuai dengan Keputusan Presiden Republik Indonesia dengan Nomor 26 Tahun 1988, pada tahun 2006 diadakan perubahan struktur baik di BPN pusat, kanwil, maupun kantor pertanahan kota/kabupaten.

Adapun visi dari Badan Pertanahan Nasional Republik Indonesia, yaitu :"Menjadi lembaga yang mampu mewujudkan tanah dan pertanahan untuk sebesar-besar kemakmuran rakyat, serta keadilan dan keberlanjutan sistem kemasyarakatan, kebangsaan dan kenegaraan Republik Indonesia." Untuk mencapai visi tesebut, maka BPN membuat misi, yaitu mengembangkan dan menyelenggarakan politik dan kebijakan pertanahan untuk :

Peningkatan kesejahteraan rakyat, penciptaan sumber-sumber baru kemakmuran rakyat, pengurangan kemiskinan dan kesenjangan pendapatan, serta pemantapan ketahanan pangan. Peningkatan tatanan kehidupan bersama yang lebih berkeadilan dan bermartabat dalam kaitannya dengan penguasaan, pemilikan, penggunaan dan pemanfaatan tanah (P4T). Perwujudan tatanan kehidupan bersama yang harmonis dengan mengatasi berbagai sengketa, konflik dan perkara pertanahan di seluruh tanah air dan penataan perangkat hukum dan sistem pengelolaan pertanahan sehingga tidak melahirkan sengketa, konflik dan perkara di kemudian hari. Keberlanjutan sistem kemasyarakatan, kebangsaan dan kenegaraan

Indonesia dengan memberikan akses seluas-luasnya pada generasi yang akan datang terhadap tanah sebagai sumber kesejahteraan masyarakat. Menguatkan lembaga pertanahan 
sesuai dengan jiwa, semangat, prinsip dan aturan yang tertuang dalam UUPA dan aspirasi rakyat secara luas.Prona ditekankan pada masyarakat ekonomi lemah, dan bagi masyarakat yang tidak atau kurang mampu,mereka di bebaskan untuk tidak dibebani dengan biaya-biaya pendaftaran, kecuali mereka yang termasuk golongan mampu. Bagi yang di nanyatakan golongan mampu, tetapi yang bersangkutan menyatakan dirinya termasuk golongan ekonomi lemah dan ingin menjadi peserta Prona yang pembiyaannya diatur dalam Keputusan Mentri Dalam Negeri Nomor 220 Tahun 1981, wajid membuktian kan dengan surat keterangan Kepala Desa/Lurah yang dikuatkan oleh camat.

Mengingat biaya yang diperlukan dalam program Prona cukup tinggi, sedangkan pensertifikatan secara massal harus tetap berjalan, pemerintah telah mengambil kebijakan untuk mendahulukan pensertifikatan tanah bagi golongan mampu. Hal ini ditempuh untuk memperoleh dana dari mereka yang termasuk golongan mampu. Penggolongan peserta penggolongan peserta Prona dimaskdudkan tidak lain dengan keadilan dan pemerataan terhadap sesawa WNI pemilik atau pemegang hak atas tanah, dalam rangka mendapat kepastian hukum hak-hak atas tanah yang bersangkutan. Pelaksaan Prona dan sekaligus untuk mewujudkan adanya peningkatan pelayanan kepada masyarakat, beberapa orang tergolong ekonomi kuat tidak ditolak menjadi peserta Prona bagi golongan ekonomi lemah. Sudah tentu bagi yang bersangkutan, kebijaksanaan itu sangat menguntukangkan sebab jumlah pungutan biaya yang harus dibayarkan akan jauh lebih ringan, karena sebagian dari kewajibannya itu telah di subsidikan oleh pemerintah namun sebaliknya, bagi negara kebijakan itu dari segi pemasukan keungan sangat merugikan. Negara harus menerimah pemasukan dari golongan ekonomi kuat, tetapi kenyataannya justru negara mengeluarkan subsidi untuk mereka.

Banyaknya keluhan dari masyarakat terkait dengan pelayanan sertifikat tanah diantaranya birokrasi yang rumit dan tidak praktis, ketidak 
pastian waktu dan biaya sampai dengan penerbitan sertifikat tanah yang tidak sesuai dengan nama pemilik yang membuat banyak tanah yang bersengketa. Hal ini membuat perlunya ada perhatian terhadap proses pelayanan sertifikat tanah tersebut. Oleh karna itu, Badan Pertanahan Negara (BPN) Kabupaten pinrang menyerahkan ratusan sertifikat Prona (Proyek Nasional) kepada masyarakat yang berdomisili di pesisir Kelurahan Pallameang Kecamatan Mattiro Sompe, Kabupaten Pinrang. Kepala BPN Pinrang, Suarni Labeda SH.MH membenarkan penyerahan sertifikat prona itu secara simbolis. Menurutnya, program ini merupakan kegiatan tahunan yang dilaksanakan oleh BPN Secara berkesinambungan. "untuk tahun ini dilaksanakan di Kelurahan Pallameang Kecamatan Mattiro Sompe," Nelayan penerima sertifikat terdiri dari Nelayan tangkap sebanyak 100 orang, Nelayan Budidaya 44 orang dan prona sebanyak 150 buah sertifikat . Kami berharap, sertifikat ini dapat membantu para nelaya. BPN Kabupaten Pinrang selama ini telah menyelesaikan dua bidang Aset
Badan Milik Negara (BMN) atas nama TNI, BPN Pinrang. Hal itupun, direward penghargaan dari Direktorat Jendral Keuangan Negara ( DJKN). Sertifikat itu juga bisa dimanfaatkan menjadi jaminan guna menambah modal usaha nelaya, Pelayanan Sertifikat tanah pada kantor petanahan Kabupaten Pinrang sangat Pentng Sebagai upaya peningkatan pelayanan dalam mencapai suatu kepuasan masyarakat sehingga diharapkan akan dapat meningkatkan jumlah masyarakat yang memfanfaatkan pelayanan Sertifikat tersebut. Dalam penelitian ini, untuk mengetahui gambran umum Bagaimana Kualitas Pelayanan PRONA(Proyek operasi nasional agraria) di Kecematan Mattiro Sompe Kabupaten Pinrang, dalam kualitas pelayanan yang baik, Adapun indikator Kualitas Pelayanan sebagai berikut:

Pada poin Ketepatan waktu pelayanan Tjiptono mengungkapkan ketepatan waktu pelayanan, termasuk didalamnya waktu untuk menunggu selama transaksi maupun maupun pembayaran. dalam pengurusan 
sertifikat tanah terkait dengan kecepatan pelayanan terganung dengan berkas yang di butuhkan dalam pengurusan sertifikat tersebut. Apabila berkas yang di perlukan lengkap maka sertifikat tanah bisa cepat terselesaikan. Berbeda dengan pendapat masyarakat bahwa sertifikat tanah cepat selesai karna seritifikat gratis atau Program pemerintah. standar pelayanan pada masyarakat sesuai dengan kewenangan yang diberikan oleh pemerintah pusat pada pemerintah daerah tidak ada perbedaan bahwa sertifikat gratis cepat selesai karna masing-masing punya waktu yang di tentukan. Pelaksaan Prona dan sekaligus untuk mewujudkan adanya peningkatan pelayanan kepada masyarakat, beberapa orang tergolong ekonomi kuat tidak ditolak menjadi peserta Prona bagi golongan ekonomi lemah. Sudah tentu bagi yang bersangkutan, kebijaksanaan itu sangat menguntukangkan sebab jumlah pungutan biaya yang harus dibayarkan akan jauh lebih ringan.

Akuransi Pelayanan menurut pendapat Tjiptono (2011) yang mengatakan Akuransi Pelayanan, yaitu meminimalkan kesalahan dalam pelayanan maupun transanksi. berdasarkan prosedur pelayanan baik dari segi kejelasan persyaratan administrasi maupun kesederhanaan alur pelayanan pertanahan sudah dapat dikatakan baik, jelas dan mudah dipahami oleh masyarakat. Dengan kata lain dapat dinyatakan bahwa antara kepuasan pelayanan dengan kepuasan masyarakat mempunyai hubungan yang sangat erat sekali. Kualitas yang diberikan kantor harus diikuti dengan rasa kepuasan dari masyarakat, Agar kualitas pelayanan yang baik memberikan kepuasan kepada masyarakat maka perlu adanya pembenahan dari instansi sehingga kepuasan sesungguhnya dapat terwujud.

Sikap santun dan ramah
petugas dalam memberikan
pelayanan sertifikat tanah belum
maksimal. Hal ini dapat kita liat
dengan wawancara yang di lakukan
oleh penulis menyebutkan bahwa
masih terdapat beberapa pegawai
yang terkesan cuek dalam
memberikan pelayanan sertifikat
tanah, jika pelayanan yang berada
jauh di bawah standar atau tidak


sesuai dengan ekspektasi pelayanan yang di harapkan oleh masyarakat maka konsumen tersebut akan memberikan feedback buruk, serta bukan tidak tidak mungkin akan menjadi lebih baik, Dengan memahami keinginan dan kebutuhan seseorang, memberikan kemudahan dalam pelayanan, melakukan komunikasi yang efektif kepada masyarakat, memberikan perhatian penuh terhadap keluhan masyarakat serta memahami kebutuhan para masyarakat akan membuat kepuasan masyarakat akan semakin meningkat.

Kemudahan mendapatkan pelayanan seperti yang di kemukakan Tjiptono ( 2011) kemudahan mendapatkan pelayanan yaitu, seperti tersedianya sumber daya manusia untuk membantu melayani konsumen, serta fasilitas pendukung seperti komputer untuk mencari ketersedian informasi, dan lain sebagainya. Kemudahan Pelayanan berdasarkan akses informasi dan komunikasi semuanya telah disiapkan, baik informasi terkait dengan pengurusan sertifikat tanah maupun informasi lainnya. Adapun keluhan pelanggan itu muncul karena masyarakat kurang paham dengan apa yang telah disedikan. Serta untuk informasi terkait pengurusan sertifikat dan lainlainnya itu sudah ada di situ resmi www.bpn.go.idmemberikan kemudahan kepada masyarakat dalam menyampaikan masukannya dalam hal ini perlu untuk dilakukan dan memastikan pelanggan memperoleh informasi dalam bahasa yang bisa mereka pahami serta mendengarkan mereka Namun akan lebih baik apabila semua usaha perbaikan kualitas pelayanan kantor ini agar dilakukan secara berkelanjutan dan masyarakat lebih mengerti.

Kenyamanan Konsumen sesuai pendapat Tjiptono (2011) yang mengatakan bahwa kenyamanan konsumen berdasarkan Lokasi, tempat parkir, ruang tunggu yang nyaman, aspek kebersihan , ketersedian informasi, dan lain sebagainya. pegawai kantor Pertanahan Kabupaten Pinrang Berkaitan dengan Kenyamanan Konsumen maka Kualitas Pelaynan Proyek Operasi Nasional Agrari (PRONA) di kantor Pertanahan Kabupaten Pinrang sudah cukup baik, Kualitas Pelayanan merupakan hal 
yang sangat penting untuk dapat dikelola dengan baik, bila menginginkan adanya kepuasan yang dirasakan oleh masyarakat seperti tersedianya informasi ,ruang tunggu yang nyaman, aspek kebersihan serta tempat parkir yang luas.Dengan demikian maka kualitas pelayanan yang baik maupun buruk tergantung pada konsisten dalam memenuhi harapan para konsumennya. Penejelasan menurut Ridwan dan Sodik Sudrajat (2009) Faktor pendukung sangat penting apabila dari salah satu faktor tersebut tidak ada, maka pelayanan akan sangat terasa kurang maksimal.Waktu Penyelesaian Sertifikat dalam Tahun Anggaran pelaksanaan kegiatan PRONA ini tentu akan selesai dalam satu tahun anggaran sesuai dengan ketentuan yang berlaku. proyek penyertifikatan tanah secara massal yang memperoleh dukungan dana atau subsidi dari pemerintah melalui Anggaran Pendapatan dan Belanja Negara (APBN) yang dibebankan kepada Badan Pertanahan Nasional. Sehingga Kebijaksanaan ini dimaksudkan agar setiap masyarakat golongan ekonomi lemah dengan memperhatikan aspek keberpihakan dapat memiliki sertifikat hak milik atas tanah dengan biaya yang lebih murah. Program ini diadakan dengan tujuan untuk memberikan jaminan kepastian hukum kepada para pemegang hak atas tanah.

Dukungan Masyarakat terlihat antusian warga untuk mendaftarkan tanahnya melalui sertifikat prona penyertifikatan yang dilakukan atas keinginan sendiri. Keuntungan tersebut, adanya subsidi dari pemerintah ini, pemohon sertifikat mendapatkan keringanan biaya dan cepatnya proses penerbitan sertifikat sesuai dengan waktu yang telah ditetapkan. Adapun faktor penghambat dalam hal ini dapat memperlambat proses pemberian pelayanan kepada masyarakat berikut menurut

Zeithmal ( dalam Kurniawan, 2005) yang mengatakan bahwa terdapat kendala dalam pelayaan publik yakni pemberian ukuran yang salah dalam pelayanan itu sendiri seperti Keterbatasan Jumlah SDM Khususnya Bidang Pengukuran untuk mengurangi beban petugas pengukur, sebelum dilakukan pengukuran masyarakat sudah diminta untuk 
memasang tanda batas terlebih dahulu sebelum dilakukan pengukuran, dengan mendapat persetujuan dari tetangga samping kiri, kanan, depan, belakang dan setiap petugas di beri waktu 10 hari pengukuran tanah karan kurangnya tenaga pengukur.kualitas pelayanan di instansi pemerintahan telah memiliki standar-standar tersendiri yang harus dipenuhi Salah satu tempat yang memerlukan perhatian terkait kualitas pelayanannya adalah instansi pemerintahan. Kerap kali kita mengeluh tentang pelayanan di instansi pemerintahan yang cenderung kurang atau tidak memenuhi kriteria yang diharapkan. Namun pada dasarnya standar dipenuhi Pelaksaan Prona dan sekaligus untuk mewujudkan adanya peningkatan pelayanan kepada masyarakat, beberapa orang tergolong ekonomi kuat tidak ditolak menjadi peserta Prona bagi golongan ekonomi lemah. Sudah tentu bagi yang bersangkutan, kebijaksanaan itu sangat menguntukangkan sebab jumlah pungutan biaya yang harus dibayarkan akan jauh lebih ringan, karena sebagian dari kewajibannya itu telah di subsidikan oleh pemerintah. Maka dari itu Dengan memahami keinginan dan kebutuhan seseorang, memberikan kemudahan dalam pelayanan, melakukan komunikasi yang efektif kepada konsumen, memberikan perhatian penuh terhadap keluhan konsumen serta memahami kebutuhan para konsumen akan membuat kepuasan konsumen akan semakin meningkat. Hasil penelitian yang dilakukan oleh Sarwono dan Rohmad (2013) membuktikan adanya pengaruh signifikan antara kualitas layanan pada kepuasan masyarakat. Kualitas pelayanan merupakan hal yang sangat penting untuk dapat dikelola dengan baik, bila menginginkan adanya kepuasan yang dirasakan oleh masyarakat. Dengan kata lain dapat dinyatakan bahwa antara kepuasan pelayanan dengan kepuasan masyarakat mempunyai hubungan yang sangat erat sekali.Kemudian menurut Kotler (2000:25), kualitas pelayanan merupakan totalitas dari bentuk karakteristik barang dan jasa yang menunjukkan kemampuannya untuk memuaskan kebutuhan pelanggan, baik yang nampak jelas maupun yang tersembunyi. Bagi perusahaan yang bergerak di sektor 
jasa, pemberian pelayanan yang berkualitas pada pelanggan merupakan hal mutlak yang harus dilakukan apabila perusahaan ingin mencapai keberhasilan.

Hak pelayanan yang diterima oleh masyarakat terasa belum memenuhi harapan semua pihak baik dari kalangan masyarakat umum maupun dari kalangan pemerintah sendiri. Jadi tidak heran lagi sering mendengarkan tuntutan perubahan sering ditujukan kepada aparatur pemerintah, menyangkut pelayanan publik yang di berikan kepada masyarakat. Rendahnya mutu pelayanan publik merupakan citra buruk pemerintah di tengah masyarakat, bagi masyarakat yang pernah berurusan dengan birokrasi selalu mengeluhkan, dan kecewa terhadap tidak layaknya aparatur dalam memberikan pelayanan. Kualitas merupakan suatu kondisi dinamis yang berhubungan dengan hasil kerja, manusia/tenaga kerja, proses dan tugas, serta lingkungan yang memenuhi atau melebihi harapan konsumen atau masyarakat. Salah satu tempat yang memerlukan perhatian terkait kualitas pelayanannya adalah instansi pemerintahan. Kerap kali kita mengeluh tentang pelayanan di instansi pemerintahan yang cenderung kurang atau tidak memenuhi kriteria yang diharapkan. Namun pada dasarnya standar dipenuhi. Hal ini sesuai dengan pendapat Kotler (2009; 98) yang menyatakan bahwa ada hubungan yang erat antara pelayanan dengan kepuasan seseorang serta keuntungan instansi dimana kualitas yang lebih tinggi menghasilkan kepuasan yang lebih tinggi. Dengan memahami keinginan dan kebutuhan seseorang, memberikan kemudahan dalam pelayanan, melakukan komunikasi yang efektif kepada konsumen, memberikan perhatian penuh terhadap keluhan konsumen serta memahami kebutuhan para konsumen akan membuat kepuasan konsumen akan semakin meningkat.

\section{KESIMPULAN}

Kualitas pelayanan adalah sebuah tingkatan keunggulan yang diharapkan, untuk memenuhi harapan konsumen. Kualitas pelayanan tidak di pandang berdasarkan sudut pandang prosedur melainkan dari 
persepsi orang yang menerimah pelayanan. bahwa dalam pengurusan sertifikat tanah terkait dengan kecepatan pelayanan tergantung dengan berkas yang di butuhkan dalam pengurusan sertifikat tersebut. Apabila berkas yang di perlukan lengkap maka sertifikat tanah bisa cepat terselesaikan. Berbeda dengan pendapat masyarakat bahwa sertifikat tanah cepat selesai karna seritifikat gratis atau Program pemerintah. akuransi pelayanan berdasarkan prosedur pelayanan baik dari segi kejelasan persyaratan administrasi maupun kesederhanaan alur pelayanan pertanahan sudah dapat dikatakan baik, jelas dan mudah dipahami oleh masyarakat. bahwa Sikap santun dan ramah petugas dalam memberikan pelayanan sertifikat tanah belum maksimal. Hal ini dapat kita liat dengan terdapat beberapa pegawai yang terkesan cuek dalam memberikan pelayanan sertifikat tanah. informasi terkait dengan pengurusan sertifikat tanah maupun informasi lainnya. Adapun keluhan pelanggan itu muncul karena masyarakat kurang paham dengan apa yang telah disedikan. Serta untuk informasi terkait pengurusan sertifikat dan lain-lainnya itu sudah ada di situ resmi www.bpn.go.id. Berkaitan dengan kenyamanan konsumen maka kualitas pelaynan proyek operasi Nasional Agrari (PRONA) di kantor Pertanahan Kabupaten pinrang sudah cukup baik, Kualitas pelayanan merupakan hal yang sangat penting untuk dapat dikelola dengan baik, bila menginginkan adanya kepuasan yang dirasakan oleh masyarakat. pelaksanaan kegiatan PRONA ini tentu akan selesai dalam satu tahun anggaran sesuai dengan ketentuan yang berlaku. antusian warga untuk mendaftarkan tanahnya melalui sertifikat prona penyertifikatan yang dilakukan atas keinginan sendiri. Kurangnya tenaga pegukur yang menjadi salah satu hambatan dalam peneyelesaian pengukuran tanah.

\section{DAFTAR PUSTAKA}

Adrian, Sutedi, 2014. Hak AtasTanah, Jakarta: Sinar Gartifaka

Hardiansyah. 2010. Kualitas Pelayanan Publik Konsep, Dimensi, Indikator dan Implementasinya. Yogyakarta: PT.Gava Media.

Kurniawan, Agung. 2005. Transformasi Pelayanan 
Publik. Yogyakarta:

Pembaruan.

MN. Nasution. 2005. Manajemen

Mutu Terpadu (Total Quality

Management). Jakarta: Glalia Indonesia.

Ridwan, Juniarso dan Sodiak Sudrajat, acmad. 2009. Hukum Administrasi Negara dan Kebijakan Pelayanan Publik . Bandung: Nuansa.

R.Subekti, R Tjirosudibio. 2001. Kitab Undang-undang Hukum Perdata, cet Ke-31. Jakarta: Prandhya Paramitha.

Tjiptono, Fandy. 2001. Strategi Pemasaran. Yogyakarta: Edisi Pertama.

Urip, Santoso. 2014. Hukum Agraria dan Hak-hak atas Tanah. Jakarta: Kencana Prenada Media Grup.

Undang-undang Nomor 32 Tahun 2004 Tentang Pemerintah Daerah.

Undang-undang Nomor 5 Tahun 1960 Tentang Peraturan Dasar Pokok-pokok Agraria dan Pelaksanannya. 